\title{
PCR-Based Assays for the Detection of Puccinia horiana on Chrysanthemums
}

\author{
Kerry F. Pedley, U.S. Department of Agriculture, Agricultural Research Service, Foreign Disease-Weed Science \\ Research Unit, 1301 Ditto Ave., Ft. Detrick, MD 21702
}

\begin{abstract}
Pedley, K. F. 2009. PCR-based assays for the detection of Puccinia horiana on chrysanthemums. Plant Dis. 93:1252-1258.

Puccinia horiana, the causal agent of chrysanthemum white rust, is a pathogen of quarantine status in many countries where Chrysanthemum $\times$ morifolium cultivars are grown. Historically, identification protocols for white rust relied upon macroscopic symptom development and microscopic examination of infected leaves for teliospores. Symptoms become visible 7 to 10 days after initial infection under favorable conditions followed by the production of telia. Infected plants can therefore evade detection before symptoms and fruiting bodies are evident. Conventional and real-time polymerase chain reaction (PCR) assays were developed to detect $P$. horiana using primers designed to amplify portions of the internal transcribed spacer (ITS) regions of the nuclear ribosomal DNA (rDNA). The species-specific primers could detect the pathogen from 1 ng of DNA isolated from infected leaf tissue in conventional PCR assays and from $1 \mathrm{pg}$ in realtime PCR assays. While both assays were capable of detecting $P$. horiana in symptomatic tissue, the greater sensitivity offered by the real-time PCR assay makes it more reliable for detecting the pathogen during the latent stage of infection. The $P$. horiana primers did not amplify the rDNA target using DNA isolated from leaf tissue infected with $P$. chrysanthemi.
\end{abstract}

Chrysanthemum white rust, caused by Puccinia horiana Henn., is an economically important disease that infects most florist's chrysanthemum (Chrysanthemum $\times$ morifolium) cultivars grown worldwide for cut flower and potted plant production (13). The disease was first discovered in Japan in 1895 (12) and described by Hennings (11) in 1901. Although confined to Japan and China until 1963 (5), global trade of chrysanthemums has since disseminated $P$. horiana throughout the world. $P$. horiana has now been found virtually everywhere chrysanthemums are grown or shipped, and it is regulated

Corresponding author: K. F. Pedley

E-mail: kerry.pedley@ars.usda.gov

The use of trade, firm, or corporation names in this publication is for the information and convenience of the reader. Such use does not constitute an official endorsement or approval by the United States Department of Agriculture or the Agricultural Research Service of any product or service to the exclusion of others that may be suitable.

* The $\boldsymbol{e}$-Xtra logo stands for "electronic extra" and indicates that two supplementary figures and one supplementary table are available online.

Accepted for publication 19 July 2009.

doi:10.1094/PDIS-93-12-1252

This article is in the public domain and not copyrightable. It may be freely reprinted with customary crediting of the source. The American Phytopathological Society, 2009. as a quarantine organism in most countries (3).

$P$. horiana is an obligate biotrophic pathogen that primarily infects fresh tissue of growing plants, although older leaves can also become infected (8). Disease symptoms include the formation of raised, buff or pinkish pustules (sori) on the lower leaf surface that turn white at maturity (13), and tan as they age. $P$. horiana is a microcyclic rust, producing only teliospores and basidiospores. Germinating teliospores produce a basidium from which unicellular basidiospores are discharged (13). It is the dispersal of basidiospores that accounts for the rapid spread of white rust, which can be distributed by air currents to a distance of at least $700 \mathrm{~m}$ (23). Upon germination, basidiospores produce a germ tube that directly penetrates susceptible leaf tissue. The period between infection and symptom development is normally 7 to 10 days $(8,24)$, and teliospores are typically formed a few days later (13). The incubation period can be prolonged for several weeks when infected plants are exposed to temperatures in excess of $30^{\circ} \mathrm{C}$ (24).

The use of clean nursery stock and routine scouting for disease are essential management practices for the control of white rust. Until recently (1), identification protocols for $P$. horiana relied upon macroscopic symptoms and morphological features of the sori as well as microscopic examination of the teliospores. For this reason, during the initial stages of infec- tion, the pathogen can often elude detection. In greenhouses and nurseries, early and accurate identification of white rust is essential to limit the spread of the pathogen and to ensure clean stock for propagation. More versatile molecular-based diagnostic methods are beneficial to chrysanthemum growers and may assist in border interceptions and field inspections in countries where $P$. horiana is regulated as a pathogen of quarantine status.

The polymerase chain reaction (PCR) with species-specific primers is particularly well-suited for the identification of phytopathogenic fungi, because it does not require the presentation of fully developed morphological features, and it can be used to confirm the presence of a pathogen during the early stages of infection. The utility of the ribosomal DNA (rDNA) internal transcribed spacer (ITS) regions 1 and 2 for the production of specific primers has been shown to be a successful strategy for developing diagnostic assays for many plant-pathogenic fungi (10), including several rusts $(6,9,14,25)$. The ITS regions are ideal for such assays because they show considerable variation among individual fungal species but generally are conserved within a species (21). Additionally, PCR assays based upon the ITS regions are favored since rDNA is present in multiple copies in most fungal genomes (21), making them more sensitive than assays that amplify single-copy genes.

Many chrysanthemum cultivars are also susceptible to Puccinia chrysanthemi, the causal agent of chrysanthemum brown rust (17). Early symptoms of brown rust consist of pale yellow flecks on the upper and lower leaf surface, and as the disease progresses, brown powdery uredia form consisting mainly of abundant, darkly pigmented urediniospores (13). Brown rust and white rust are therefore easily distinguished in late stages of disease by the spores they produce. The shared ancestry of the rusts that infect chrysanthemums must therefore be considered during the design of primers so that the primers intended to detect $P$. horiana do not amplify a target from the DNA of $P$. chrysanthemi.

The objectives of this study were to: (i) sequence and compare the ITS regions of $P$. horiana isolates collected from several distinct geographical locations; (ii) develop primers specific to $P$. horiana based 
on the rDNA ITS regions to be used for conventional PCR and real-time PCR assays; (iii) test the efficacy of the PCRbased detection on early and late stage infected chrysanthemum leaf tissue; and (iv) test the specificity of the primers using DNA isolated from chrysanthemum leaves infected by $P$. chrysanthemi.

\section{MATERIALS AND METHODS}

Fungal specimens and plant materials. $P$. horiana isolates were obtained from border interceptions and field inspections in Arizona, California, Pennsylvania, and Texas by APHIS inspectors (Table 1). A single sample of $P$. chrysanthemi (consisting of multiple infected leaves) was obtained from California, but the pathogen was not propagated. Chrysanthemum varieties used throughout this study included Cherry Pomona, Amber Pomona, Delano, Erica, and Pam (Yoder Brothers, Inc., Alva, FL).

Pathogen propagation and inoculation. All manipulations involving P. horiana samples and the propagation of $P$. horiana field isolate PhCA3 were conducted inside the USDA-ARS, Foreign Disease-Weed Science Research Unit Biological Safety Level 3 (BSL-3) Plant Pathogen Containment Facility under the appropriate USDA-APHIS permit (15). For routine propagation, infected leaves (3 to 4 weeks postinoculation) were macerated with a razor blade in approximately $10 \mathrm{ml}$ of $\mathrm{H}_{2} \mathrm{O}$ with a drop of Tween 20 . The tissue was then suspended in $50 \mathrm{ml}$ of $\mathrm{H}_{2} \mathrm{O}$ and poured onto chrysanthemum plants propagated from rooted cuttings and grown on a greenhouse bench with periodic misting. Symptoms developed in approximately 8 to 10 days, and telia were observed approximately 2 weeks after inoculation. For experiments involving infected, asymptomatic tissue, two inoculation methods were used. In one method, infected leaf tissue ( 3 weeks postinoculation) containing a single sorus was removed from leaves with a razor blade and placed directly on the upper surface of the leaves of uninfected plants. The site of inoculation was marked on the leaf surface with an ink marker, and the inoculum was kept in place for 2 days. Periodic misting of the plants was maintained to provide favorable conditions for white rust infection. Alternatively, a modified version of the inoculation method described by Firman and Martin (8) was used. Briefly, a piece of an infected leaf containing a single sorus was secured to the inside of a 10$\mathrm{cm}$ petri dish lid using tape. A single $P$. horiana-free leaf was placed below the inoculum. A small piece of wetted filter paper was placed inside, and the dish was sealed with Parafilm laboratory film to maintain a high level of humidity. At a specified number of days postinoculation (dpi) the leaves were washed to remove any spores or fungal tissue from the sur- face, and $1 \mathrm{~cm}^{2}$ leaf disks were removed from the site of inoculation and frozen at $-80^{\circ} \mathrm{C}$ until DNA extractions were performed.

DNA extraction. Genomic DNA was isolated from leaf tissue collected from either healthy or infected plants. For each sample, DNA was extracted from one to three $1 \mathrm{~cm}^{2}$ leaf disks that were frozen and ground to a fine powder in liquid nitrogen. Genomic DNA was extracted using a modified hexadecyltrimethylammonium bromide (CTAB) protocol (18). Briefly, DNA extraction buffer $(100 \mathrm{mM}$ Tris, $\mathrm{pH}$ 7.5; $1 \%$ CTAB; $0.7 \mathrm{M} \mathrm{NaCl} ; 10 \mathrm{mM}$ EDTA; $1 \%$ 2-mercaptoethanol; $0.3 \mathrm{mg} / \mathrm{ml}$ proteinase $\mathrm{K}$ ) was added to the ground tissue and incubated at $65^{\circ} \mathrm{C}$ for $30 \mathrm{~min}$, followed by two rounds of chloroform:isoamyl alcohol (1:1) extraction, and precipitated with 2-propanol. DNA was resuspended in TE buffer containing 1 $\mathrm{mg} / \mathrm{ml} \mathrm{RNase}$. The extracted DNA of each sample was quantified using a Nanodrop NO-1000 spectrophotometer (Nanodrop Technologies, Wilmington, DE) and adjusted to a final concentration of $100 \mathrm{ng} / \mu \mathrm{l}$ for PCR. To obtain genomic DNA to be used for cloning purposes only, DNA was isolated using the Qiagen DNeasy Plant Mini kit (Valencia, CA) following the recommendations of the manufacturer. Puccinia graminis f. sp. tritici used as a control for real-time PCR assay specificity was kindly provided by L. Szabo (USDA, ARS Cereal Disease Laboratory, St. Paul, $\mathrm{MN})$.

ITS amplification, cloning, and sequencing. Amplification of select rDNA regions from $P$. horiana and $P$. chrysanthemi was performed with the universal primer ITS5 (21) and a rust-specific primer, Rust1 (14) (Table 2). PCR was performed in $25-\mu$ reaction mixtures containing $1 \times$ ThermoPol buffer (New England Biolabs, Beverly, MA), $0.2 \mathrm{mM}$ dNTP, $400 \mathrm{nM}$ of each primer, $100 \mathrm{ng}$ template DNA (genomic DNA isolated from environmental samples), and 5 units Taq DNA Polymerase (New England Biolabs) using a Mastercycler Gradient Thermocyler (Eppendorf AG, Germany), with initial denaturation at $94^{\circ} \mathrm{C}$ for $90 \mathrm{~s}$, followed by 35 cycles of $94^{\circ} \mathrm{C}$ for $30 \mathrm{~s}, 58^{\circ} \mathrm{C}$ for $30 \mathrm{~s}, 72^{\circ} \mathrm{C}$ for $60 \mathrm{~s}$, and a final extension at $72^{\circ} \mathrm{C}$ for $2 \mathrm{~min}$. Amplified products were resolved on $1 \%$ agarose gel, and the bands were excised and purified using the Qiagen QIAquick Gel Extraction kit. Purified PCR products were cloned into pPCR2.1-TOPO using the TOPO TA Cloning kit (Invitrogen, Carlsbad, CA) and transformed into E. coli TOP10 by electroporation. Plasmid DNA was extracted from three individual clones representing each fungal specimen using a plasmid mini-prep kit (Wizard SV; Promega, Madison, WI) following the manufacturer's directions.

Table 1. Isolates of Puccinia horiana and $P$. chrysanthemi used in this study

\begin{tabular}{llccl}
\hline Isolate name & Organism & Accession no. & Year collected & Point of origin \\
\hline PhAZ1 & $P$. horiana & EU816912 & 2006 & Arizona, USA \\
PhAZ2 & P. horiana & EU816913 & 2006 & Arizona, USA \\
PhCA1 & $P$. horiana & EU816914 & 2007 & California, USA \\
PhCA2 & P. horiana & EU816915 & 2007 & California, USA \\
PhCA3 & P. horiana & EU816916 & 2007 & California, USA \\
PhCA4 & P. horiana & EU816917 & 2007 & California, USA \\
PhCA5 & P. horiana & EU816918 & 2007 & California, USA \\
PhCA6 & $P$. horiana & EU816919 & 2007 & California, USA \\
PhCA7 & $P$. horiana & EU816920 & 2007 & California, USA \\
PhPA1 & $P$. horiana & EU816921 & 2007 & Pennsylvania, USA \\
PhPA2 & $P$. horiana & EU816922 & 2007 & Pennsylvania, USA \\
PhPA3 & $P$. horiana & EU816923 & 2007 & Pennsylvania, USA \\
PhTX1 & $P$. horiana & EU816924 & 2006 & Texas, USA \\
PhTX2 & $P$. horiana & EU816925 & 2006 & Texas, USA \\
PcCA1 & $P$. chrysanthemi & EU816926 & 2007 & California, USA \\
\hline
\end{tabular}

Table 2. Polymerase chain reaction primers and fluorescent probe sequences used in this study

\begin{tabular}{|c|c|c|c|}
\hline Primer/probe & Sequence & Target species & Reference \\
\hline ITS5 & 5'-GGAAGTAAAAGTCGTAACAAGG-3' & - & (21) \\
\hline Rust1 & 5'-GCTTACTGCCTTCCTCAATC-3' & - & (14) \\
\hline $\mathrm{Ph}-\mathrm{F} 1$ & 5'-TGCATGAATTTTTGAAAGGT-3' & Puccinia horiana & This study \\
\hline $\mathrm{Ph}-\mathrm{F} 2$ & 5'-ССССТТTТTТАТTATATAACACAAG-3' & P. horiana & This study \\
\hline $\mathrm{Ph}-\mathrm{R} 1$ & 5'-CAAAAATTATTTTGTGAGAGGG-3' & P. horiana & This study \\
\hline Pc-F1 & 5'-ATTGTATGACCGCCCAAACC-3' & P. chrysanthemi & This study \\
\hline Pc-F2 & 5'-TTAACAATGGATCTCTAGGC-3' & P. chrysanthemi & This study \\
\hline Pc-R1 & 5'-ACATCTGAAATTTTTTAGAC-3' & P. chrysanthemi & This study \\
\hline $\mathrm{Cm}-\mathrm{F} 1$ & 5'-GTCGATGCGCATTTACTCGA-3' & $\begin{array}{l}\text { Chrysanthemum } \times \\
\text { morifolium }\end{array}$ & This study \\
\hline $\mathrm{Cm}-\mathrm{R} 1$ & 5'-TTCGGCCAACCACGCCATGA-3' & $\begin{array}{l}\text { Chrysanthemum } \times \\
\text { morifolium }\end{array}$ & This study \\
\hline FAM-probe & $\begin{array}{l}\text { 5'-FAM-CCAAAAGGTACACCTGTTTGA } \\
\text { GTGTCA-TAMRA-3' }\end{array}$ & - & (9) \\
\hline
\end{tabular}


The DNA was labeled with a sequencing kit (ABI Prism BigDye Terminator Cycle Sequencing Ready Reaction; Applied Biosystems, Inc., Foster City, CA). The nucleotide sequence was determined by capillary electrophoresis with a genetic analyzer (ABI Prism 310; Applied Biosystems). A consensus nucleotide sequence for each sample was aligned using the Lasergene 7 Software Suite for Sequence Analysis (DNAStar, Inc., Madison, WI).

Conventional PCR using speciesspecific primers. DNA extracted from healthy chrysanthemum leaves or those infected with either $P$. horiana (propagated isolate PhCA3) or $P$. chrysanthemi was used as the template for PCR. A sequence alignment of the cloned $P$. horiana rDNA regions and a comparative alignment between the $P$. horiana and $P$. chrysanthemi rDNA regions were visually inspected and used to manually design primers. Primers for the amplification of the chrysanthemum rDNA were manually designed based upon a Chrysanthemum $\times$ morifolium rDNA sequence (GenBank accession AB064280). All oligonucleotide primers (Table 1) were synthesized by Operon Biotechnologies (Huntsville, AL). PCR conditions were the same as used for the initial rDNA amplification. PCR products were analyzed on $1.2 \%$ agarose gels and stained with ethidium bromide. To test the sensitivity of the primers, DNA was extracted from excised $P$. horiana sori (isolate $\mathrm{PhCA} 3$ ) in an attempt to minimize contaminating plant genomic DNA. The concentration of the enriched $P$. horiana genomic DNA was adjusted to $100 \mathrm{ng} / \mu \mathrm{l}$ and serially diluted to a concentration of $0.1 \mathrm{pg} / \mu \mathrm{l}$.

Real-time PCR assay. Real-time PCR was performed using a SmartCycler (Cepheid, Inc., Sunnyvale, CA) in 25- $\mu$ l Cepheid tubes. The reactions were performed in 25 - $\mu$ l volumes containing $1 \mu \mathrm{l}$ of sample DNA (10 $\mathrm{ng} / \mu \mathrm{l}$ unless otherwise noted) and $24 \mu \mathrm{l}$ of a master mix containing 300 $\mathrm{nM}$ of each primer, $100 \mathrm{nM}$ probe (6-carboxyfluorescein [FAM] at the 5' end and 6-carboxytetramethylrhodamine [TAMRA] at the $3^{\prime}$ end; Operon Biotechnologies) (9) (Table 1), $200 \mathrm{nM}$ dNTPs, 8 $\mathrm{mM} \mathrm{MgSO}_{4}, 1 \times$ ThermoPol Buffer (New England Biolabs), $1 \times$ SCAR buffer $(0.2$ $\mathrm{mM}$ Tris [pH 8.0], $0.2 \mathrm{mg} / \mathrm{ml}$ bovine serum albumin, $150 \mathrm{mM}$ trehalose, and $0.2 \%$ Tween 20), and 1.5 units of Taq polymerase (New England Biolabs). Amplification of all samples was conducted under the following conditions: initial denaturation at $95^{\circ} \mathrm{C}$ for $2 \mathrm{~min}$, followed by 35 cycles of $95^{\circ} \mathrm{C}$ for $15 \mathrm{~s}, 60^{\circ} \mathrm{C}$ for $1 \mathrm{~min}$. The threshold cycle $(\mathrm{Ct})$ value was recorded as the cycle at which the fluorescent signal, associated with an exponential amplification of the PCR product, intersects the threshold set at 30. Every DNA sample was analyzed with triplicate realtime PCR reactions, and three biological replications were performed for each experiment unless otherwise noted. Average $\mathrm{Ct}$ values with calculated standard deviations are reported.

\section{RESULTS}

A DNA fragment of approximately 1,300 bp spanning the $5^{\prime}$ end of the $18 \mathrm{~S}$ rDNA, ITS1, the 5.8S rDNA, ITS2, and the $5^{\prime}$ end of the 28S rDNA was amplified and sequenced from 14 individual specimens of $P$. horiana and one sample of $P$. chrysanthemi. The $P$. horiana samples shared greater than 97 and $96 \%$ identity between their ITS1 and ITS2 regions, respectively (Supplemental Figures 1 and 2). The rDNA ITS regions of the isolates used in this study were also compared to the sequenced ITS regions of $18 P$. horiana isolates described by Alaei et al. (2). From 76 individual clones derived from these 18 isolates, Alaei et al. (2) described three distinct types of $P$. horiana ITS regions (designated types I, II, and III). The rDNA ITS regions of the isolates used in this study all share greater than $96 \%$ identity to the predominant, type I ITS regions.

An alignment of the $P$. horiana and $P$. chrysanthemi ITS regions (Fig. 1) illustrates the level of divergence between the two species. The ITS1 and ITS2 regions of $P$. horiana and $P$. chrysanthemi share only 68 and 73\% identity, respectively. Primers for PCR were designed using the alignment as a guide to maximize the specificity of the diagnostic assay (Table 2). The sequences of ITS regions from other chrysanthemum fungal pathogens (Didymella ligulicola, Fusarium oxysporum, Septoria obesa, Verticillium albo-atrum, V. dahliae, Erysiphe cichoracearum, Rhizoctonia solani, Sclerotinia sclerotiorum, Botryotinia fuckeliana, Stemphylium lycopersici, Itersonilia perplexans, and Pythium spp.) were also aligned against the $P$. horiana and $P$. chrysanthemi sequences to ensure that the primers designed would be specific to the intended pathogens. $P$. horiana shares less than $58 \%$ identity with the ITS1 regions of the other fungal pathogens of chrysanthemums, and less than 52\% identity within the ITS2 region. With the exception of Pc-F2, which corresponds to a conserved site within the $5.8 \mathrm{~S}$ ribosomal gene, the primers were designed to variable regions within the ITS1 and ITS2 regions to reduce the likelihood of amplifying targets other than those intended. The primer sites selected to amplify specific regions of the $P$. horiana rDNA ITS regions are not conserved in any of the other fungal pathogens of Chrysanthemum $\times$ morifolium.

Specificity of the primer sets was tested using genomic DNA isolated from greenhouse grown plants infected with either $P$. horiana or $P$. chrysanthemi, or uninfected chrysanthemums propagated in a separate greenhouse facility (Fig. 2). The $P$. horiana-specific primer sets $\mathrm{Ph}-\mathrm{F} 2 / \mathrm{Ph}-\mathrm{R} 1$ and
$\mathrm{Ph}-\mathrm{F} 1 / \mathrm{PhR} 1$ amplified single bands of 242 and 340 bp when used with DNA isolated from $P$. horiana-infected leaf tissue, but produced no PCR product when tested with DNA isolated from tissue infected by $P$. chrysanthemi. Likewise, the primer sets Pc-F2/Pc-R1 and Pc-F1/Pc-R1 designed to amplify the $P$. chrysanthemi ITS rDNA produced single bands of 243 and $395 \mathrm{bp}$ only when the DNA isolated from $P$. chrysanthemi-infected tissue was used. As expected, the primer sets designed specifically to detect either $P$. horiana or $P$. chrysanthemi did not amplify a product from genomic DNA obtained from healthy chrysanthemum leaf tissue. As a control, the sequence of the Chrysanthemum $\times$ morifolium ITS region was used to design primers that would amplify a product from both infected plants and uninfected plant controls (Table 2). A single product of 418 bp was amplified from all DNA samples using the chrysanthemum-specific primers (Fig. 2).

In preliminary trials, the $P$. horianaspecific primer set $\mathrm{Ph}-\mathrm{F} 2 / \mathrm{Ph}-\mathrm{R} 1$ that produced the 242-bp product consistently produced a more intense band than the primer set $\mathrm{Ph}-\mathrm{F} 1 / \mathrm{Ph}-\mathrm{R} 1$ that produced the larger 340-bp product (Fig. 2). As a result, the primers $\mathrm{Ph}-\mathrm{F} 2$ and $\mathrm{Ph}-\mathrm{R} 1$ were used for all subsequent experiments. To test the sensitivity of the assay, a DNA extraction from excised $P$. horiana sori was prepared. A 10 -fold serial dilution of the P. horianaenriched DNA was then used as the template in conventional PCR reactions. The P. horiana-specific primers amplified the rDNA ITS target sequence in reactions containing $1 \mathrm{ng}$ of template DNA through 35 cycles (Fig. 3A). Contaminating plant DNA could also be detected in the $P$. horiana-enriched template, as evidenced by PCR using the Cm-F1 and Cm-R1 primer set (data not shown).

Because of the greater sensitivity and rapidity offered by real-time PCR (19), the $\mathrm{Ph}-\mathrm{F} 2$ and $\mathrm{Ph}-\mathrm{R} 1$ primers were also tested in a TaqMan $5^{\prime}$ nuclease assay. These primers were used together with a FAMlabeled probe that was designed to anneal between the $\mathrm{Ph}-\mathrm{F} 2$ and $\mathrm{Ph}-\mathrm{R} 1$ primer sites within the $5.8 \mathrm{~S}$ gene (Fig. 1). To determine the sensitivity of the assay, the same 10fold serial dilutions of $P$. horiana-enriched template tested by conventional PCR were used. As little as $1 \mathrm{pg}$ of DNA could be detected using real-time PCR (Fig. 3B). Reactions containing $0.1 \mathrm{pg}$ template did not yield a positive $\mathrm{Ct}$ value, indicating no amplification of the target sequence. A negative linear relationship was found between the $\mathrm{Ct}$ value and the $\log$ of the diluted $P$. horiana-enriched DNA $\left(R^{2}=\right.$ 0.997). No-template control reactions did not produce a positive $\mathrm{Ct}$ value through 35 cycles, indicating that no amplification occurred.

To confirm the specificity of the realtime PCR assay, DNA isolated from 
P. horiana

P. chrysanthemi

P. graminis

P. horiana

P. chrysanthemi

P. graminis

P. horiana

P. chrysanthemi

P. graminis

P. horiana

P. chrysanthemi

P. graminis

P. horiana

P. chrysanthemi

P. graminis

P. horiana

P. chrysanthemi

P. graminis

P. horiana

P. chrysanthemi

P. graminis

P. horiana

P. chrysanthemi

P. graminis

P. horiana

P. chrysanthemi

P. graminis

P. horiana

P. chrysanthemi

P. graminis

P. horiana

AAAAGAAGACTTCTAAAAACCCAAAA-TTAATCTTT--

ĞT--TAATT-ATTTAGTGGATGTTGAGTGTTGCTGTCATTA--GCTCACTTTAAATATAT

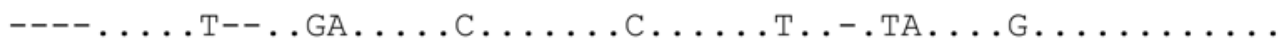

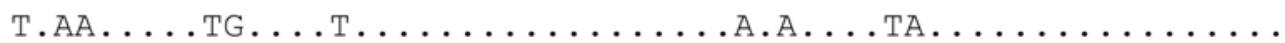

PC-R1

CAGTCACTTTTTTTTTTTTTTTTTCAAATAAGTTGGATTGACTTGGTGTAATAATTTT 531

A....--.AAAAAA...CAGA.G..GG.T.G.C...TG.A.TACAA.AA.T.T...A 494

A........................... 505

TTCATCA-----AGGAAAGTAGCAA--TACTTGCCAGCTTTTGTT--TTGAAAAAAAAAA 582

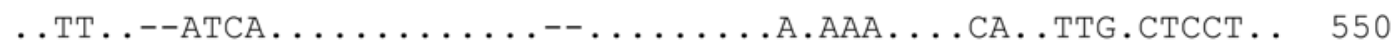
А.....САТС.........АAC.........-.-.......--- 556

P. chrysanthemi

P. graminis
617

588

588

Fig. 1. Nucleotide sequence alignment of the rDNA ITS1, 5.8S, and ITS2 regions between Puccinia horiana, P. chrysanthemi, and $P$. graminis f. sp. tritici. A consensus sequence constructed from the $P$. horiana specimens obtained for this study, a single sequenced field isolate of $P$. chrysanthemi, and $P$. graminis $\mathrm{f}$. sp. tritici are compared. The 5.8S rDNA is delineated by lowercase. The sequence and location of the $P$. horiana-specific primers and the FAM-labeled fluorescent probe are indicated in bold, and the $5^{\prime}$ to $3^{\prime}$ direction of the polymerase chain reaction (PCR) primers is shown by arrows. Primers designed to specific regions of the $P$. chrysanthemi rDNA are indicated by arrows only. 
P. chrysanthemi-infected leaf tissue was tested with the $\mathrm{Ph}-\mathrm{F} 2 / \mathrm{Ph}-\mathrm{R} 1$ primer set, and no amplification was detected. As a further control for specificity, purified $P$. graminis f. sp. tritici genomic DNA was also tested. Despite the higher level of sequence identity between the $P$. horiana and $P$. graminis f. sp. tritici ITS1 and ITS2 regions (77 and $87 \%$, respectively), the $\mathrm{Ph}-$ $\mathrm{F} 2 / \mathrm{Ph}-\mathrm{R} 1$ primer sites are not conserved in

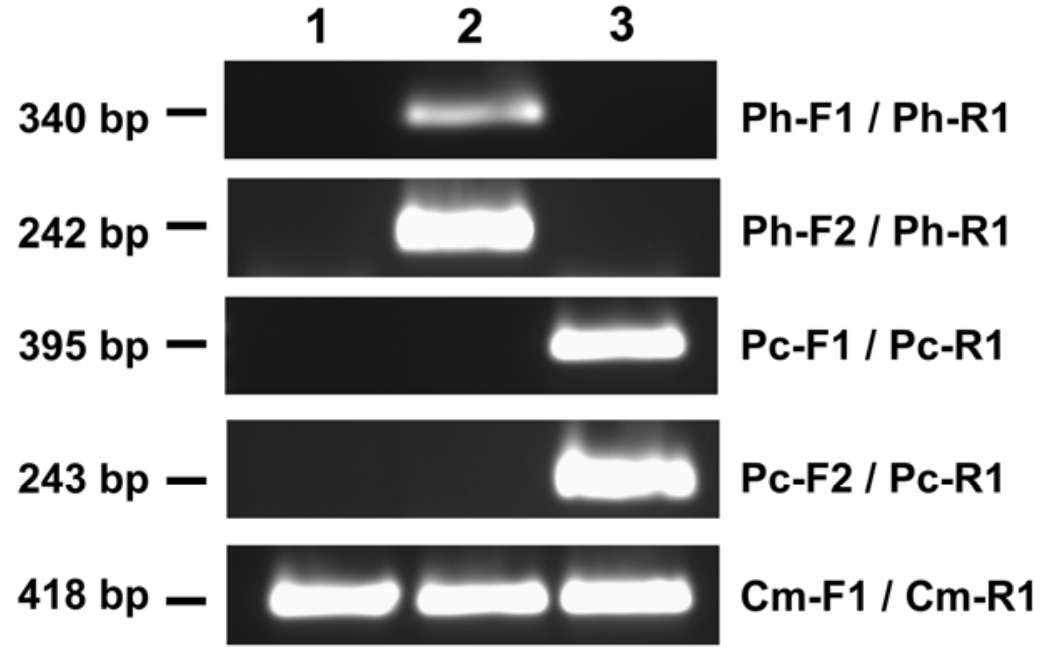

Fig. 2. Agarose gels of polymerase chain reaction (PCR) assays showing the specificity of the primers. The size of each product is indicated to the left of each gel, and the primer combinations $(\mathrm{Ph}-\mathrm{F} 1 / \mathrm{Ph}-$ $\mathrm{R} 1, \mathrm{Ph}-\mathrm{F} 2 / \mathrm{Ph}-\mathrm{R} 1, \mathrm{Pc}-\mathrm{F} 1 / \mathrm{Pc}-\mathrm{R} 1, \mathrm{Pc}-\mathrm{F} 2 / \mathrm{Pc}-\mathrm{R} 1$, or $\mathrm{Cm}-\mathrm{F} 1 / \mathrm{Cm}-\mathrm{R} 1)$ used for each assay are indicated to the right. $1=$ DNA from an uninfected plant; $2=$ DNA from a plant displaying chrysanthemum white rust symptoms; 3 = DNA from a plant displaying chrysanthemum brown rust symptoms.

A

Template DNA (ng)

\begin{tabular}{llllll}
\hline 100 & 10 & 1 & 0.1 & 0.01 & 0.001 \\
\hline & & & & & \\
\hline
\end{tabular}

\section{B}

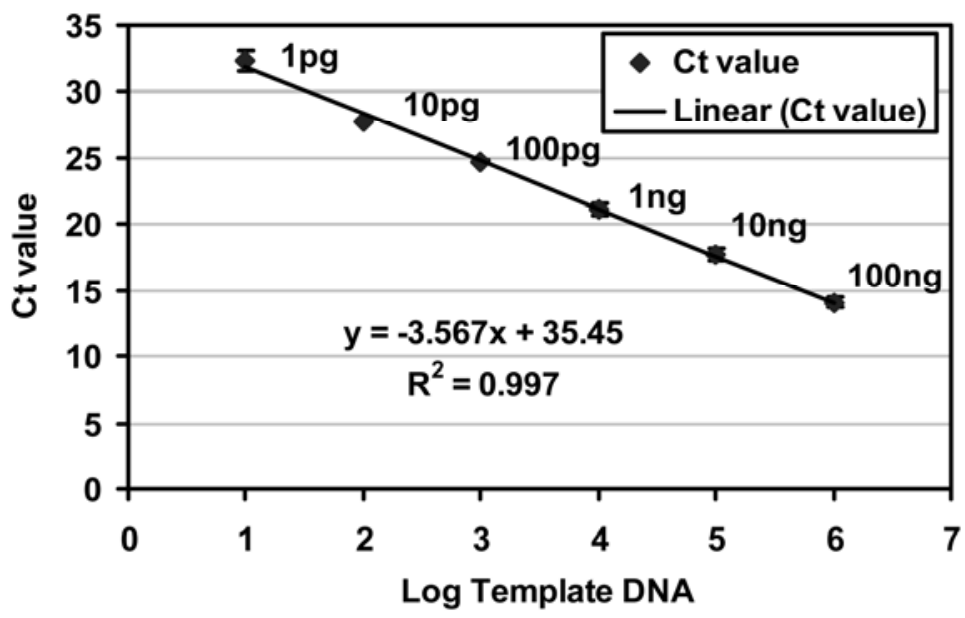

Fig. 3. Sensitivity of conventional polymerase chain reaction (PCR) and real-time PCR assay using diluted template DNA. A, Agarose gel of a conventional PCR assay using the Puccinia horianaspecific primers, Ph-F2 and Ph-R1. Amounts of DNA for each reaction are indicated. B, Correlation of cycle threshold $(\mathrm{Ct}$; number when fluorescence of sample exceeded background fluorescence) values to the log of template DNA concentration using real-time PCR with the $P$. horiana-specific primer set, $\mathrm{Ph}-\mathrm{F} 2 / \mathrm{Ph}-\mathrm{R} 1$, and the FAM-labeled probe. the $P$. graminis f. sp. tritici ITS region (Fig. 1), and they did not amplify a product from the $P$. graminis f. sp. tritici template DNA using the real-time PCR assay. To test the utility of the real-time assay on field samples, nine environmental samples visibly infected with $P$. horiana were tested using the TaqMan $5^{\prime}$ nuclease assay, and all yielded positive $\mathrm{Ct}$ values (Supplemental Table 1).

Real-time PCR was used to test genomic DNA that was isolated from chrysanthemum leaves displaying a range of disease symptoms (Fig. 4). All samples showing visible symptoms, including the earliest detectable lesions from which no teliospores could be detected (designated as stage 1 of infection), young sori producing teliospores (stage 2), and fully formed sori (stage 3), tested positive for the presence of $P$. horiana (Table 3 ). Plants exposed to the pathogen but lacking any visible white rust symptoms (stage 0 ) only produced a detectible PCR product for one out of the three trials. However, since the stage 0 tissue used for this experiment was selected randomly from plants that were merely exposed to the pathogen, it is possible that the negative results were indicative of uninfected tissue.

To more accurately assess the ability of the PCR assays to detect the presence of the pathogen in asymptomatic tissue, two methods were used to inoculate $P$. horiana-free chrysanthemum leaf tissue. The first inoculation involved direct contact with infected leaf material. For samples inoculated in this manner, the leaves showed no visible signs of infection or damage at 3 dpi. At 6 dpi, some leaves showed a slight indentation on the upper leaf surface, a symptom that often precedes the formation of a sorus on the lower leaf surface. None of the 6-dpi samples displayed any symptoms on the lower leaf surface. Both the conventional PCR and real time-PCR assays were performed on the 3-dpi and 6-dpi samples. At 3 dpi, the conventional PCR assay detected P. horiana in two of the six samples tested, whereas at 6 dpi all six samples tested positive (Table 4). Using the real-time PCR assay, all of the 3-dpi and 6-dpi samples tested positive for $P$. horiana (Table 4). Alternatively, a chrysanthemum leaf was inoculated without direct contact with the infected material. Using this method, all six of the samples collected 3 dpi tested positive using the real-time assay (Table 5). However, the conventional PCR assay failed to detect the presence of the pathogen.

\section{DISCUSSION}

The development and deployment of diagnostic technologies and protocols that allow for the early detection and accurate diagnosis of introduced plant pathogens are essential for control measures aimed at stopping the spread of disease and mini- 
mizing loss (20). While traditional diagnostic techniques based on visual examination of symptoms and/or of the pathogen itself remain the only option for many diseases, such approaches are typically slow and require confirmation by trained plant pathologists or diagnosticians. Furdisplay symptoms, and therefore cannot be effectively screened by visual inspection alone.

The aim of this work was to develop conventional and real-time PCR assays to detect $P$. horiana, the causal agent of chrysanthemum white rust. An alignment of the rDNA ITS regions from $P$. horiana isolates obtained for the current study to the rDNA ITS sequences from other fungal pathogens of chrysanthemums enabled the development of $P$. horiana-specific primers that could be used for conventional and real-time PCR assays. Using conventional PCR, the lower limit of detection was $1 \mathrm{ng}$, thermore, infected plants do not always

and although this was sufficient for reliable detection using symptomatic tissue, detection of the pathogen during the latent stage of infection was limited to leaf tissue that received a heavy inoculum, and just prior to the onset of symptom development. Thus, although the conventional PCR assay described here may have utility for confirming the presence of the pathogen in visibly infected tissue, it is of limited value during the latent stage of infection. The real-time PCR assay was 100 times more sensitive than the conventional PCR assay. Similar PCR-based assays for P. horiana have recently been reported (1). Although the lower limit of detection reported here is less than that of the real-time PCR assay reported by Alaei et al. (1), it was still sufficiently sensitive to reliably detect $P$. horiana in asymptomatic leaf tissue. Differences in DNA extraction methods, primer binding sites, PCR conditions, and the source material of the DNA (infected

Table 3. Real-time polymerase chain reaction (PCR) assay for the detection of Puccinia horiana on infected chrysanthemum leaf tissue

\begin{tabular}{lcccc}
\hline & \multicolumn{4}{c}{ Real-time PCR mean Ct $\mathbf{t}^{\mathbf{a}}$} \\
\cline { 2 - 5 } & Experiment 1 & Experiment 2 & Experiment 3 & Overall \\
\hline NC & - & - & - & - \\
Stage 0 (3 dpi) & - & $34.04 \pm 0.51$ & - & - \\
Stage 1 (9 dpi) & $29.64 \pm 0.76$ & $26.38 \pm 0.71$ & $27.31 \pm 1.06$ & $27.77 \pm 1.68$ \\
Stage 2 (15 dpi) & $24.03 \pm 0.50$ & $24.56 \pm 0.73$ & $25.67 \pm 0.54$ & $24.75 \pm 0.84$ \\
Stage 3 (21 dpi) & $21.93 \pm 0.29$ & $24.01 \pm 1.99$ & $21.22 \pm 0.05$ & $22.39 \pm 1.45$ \\
\hline
\end{tabular}

a Threshold cycle $(\mathrm{Ct})$ number when fluorescence of sample exceeded background fluorescence. Lower $\mathrm{Ct}$ number indicates fewer PCR cycles necessary for detection because of the presence of a greater amount of $P$. horiana DNA in sample; $n=3 ;-=$ fluorescence of sample did not exceed background.

${ }^{\mathrm{b}}$ Negative control, DNA extracted from uninfected plants grown in a separate greenhouse. leaves versus basidiospores) likely contribute to the differences in sensitivity of the assays developed independently by the two laboratories.

During the course of this work, an additional 76 rDNA ITS sequences derived from 18 isolates of $P$. horiana were released in GenBank by Alaei et al. (2). There are at least three distinct ITS sequence types (designated types I, II, and III) in P. horiana (2). However, types II and III appear to occur at a very low frequency in some isolates, and all isolates contain the predominant type I rDNA ITS sequences (2). Only type I sequences were found among the isolates collected in this study. A comparison of all the available $P$. horiana rDNA ITS sequences further established that the annealing sites for the FAM-probe and the $P$. horiana-specific primers (Ph-F1, Ph-F2, and Ph-R1) described herein are conserved. Furthermore, since these sequences were derived from a collection with a diverse geographical distribution, the assays based upon the $\mathrm{Ph}$ $\mathrm{F} 2 / \mathrm{Ph}-\mathrm{R} 1$ primer set should have broad applicability.

Aside from $P$. horiana, $P$. chrysanthemi is the only other Puccinia species known to infect Chrysanthemum $\times$ morifolium. It should be noted that several species, including $P$. chrysanthemi, $P$. similis, $P$. artemisiella, and $P$. absinthii have been synonymized with $P$. tanaceti over the years $(4,7,22)$, and there is currently some debate over the validity of this taxonomic classification (16). Although $P$. horiana and $P$. chrysanthemi belong to the same genus, there is significant divergence be-
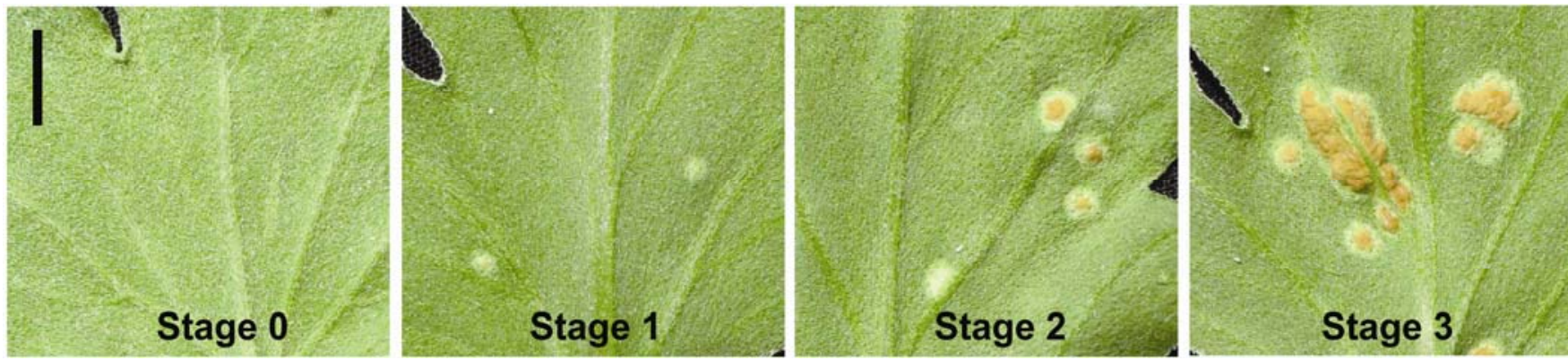

Fig. 4. Disease progression of chrysanthemum white rust. Stage 1, small, 1 to $3 \mathrm{~mm}$ lesions present on the adaxial leaf surface ( 8 to 10 days postinoculation [dpi]). Stage 2, the formation of raised, tan-colored sori indicating the formation of teliospores (14 to $16 \mathrm{dpi}$ ). Stage 3 , sori are fully formed (21 to $28 \mathrm{dpi}$ ), 0.5 to $1 \mathrm{~cm}$ in diameter. $\mathrm{Bar}=0.5 \mathrm{~cm}$.

Table 4. Conventional and real-time polymerase chain reaction (PCR) assays for the detection of Puccinia horiana on asymptomatic chrysanthemum leaf tissue directly inoculated with individual $P$. horiana telia

\begin{tabular}{lcccccccc}
\hline & \multirow{7}{*}{$\begin{array}{c}\text { Conventional } \\
\text { Sample }\end{array}$} & PCR $^{\mathbf{a}}$ & $\mathbf{1}$ & $\mathbf{2}$ & $\mathbf{3}$ & $\mathbf{4}$ & $\mathbf{5}$ & $\mathbf{6}$ \\
\cline { 3 - 9 } & 0 & - & - & - & - & - & - \\
$\mathrm{NC}^{\mathrm{d}}$ & 2 & $23.36 \pm 0.48$ & $23.87 \pm 0.26$ & $27.59 \pm 0.44$ & $32.77 \pm 0.92$ & $24.09 \pm 0.71$ & $27.07 \pm 0.64$ & $26.46 \pm 0.58$ \\
$3 \mathrm{dpi}$ & 6 & $23.69 \pm 0.37$ & $25.30 \pm 0.07$ & $23.42 \pm 0.39$ & $22.60 \pm 0.32$ & $24.72 \pm 1.02$ & $26.16 \pm 0.45$ & $24.32 \pm 0.44$ \\
$6 \mathrm{dpi}$ & mean $^{\mathbf{c}}$ & &
\end{tabular}

a Number of samples that tested positive out of six independent inoculations or uninfected controls.

b Threshold cycle.

${ }^{\mathrm{c}}$ Experimental mean and standard deviation based on six independent inoculations.

${ }^{\mathrm{d}}$ Negative control, DNA extracted from uninfected plants grown in a separate greenhouse.

e Days postinoculation. 
Table 5. Conventional and real-time polymerase chain reaction (PCR) assays for the detection of Puccinia horiana on asymptomatic chrysanthemum leaf tissue inoculated without direct contact with infected leaf material

\begin{tabular}{|c|c|c|c|c|c|c|c|c|}
\hline \multirow[b]{2}{*}{ Sample } & \multirow{2}{*}{$\begin{array}{c}\text { Conventional } \\
\text { PCR }^{\mathbf{a}}\end{array}$} & \multicolumn{6}{|c|}{ Real-time PCR mean $\mathrm{Ct}^{\mathrm{b}}$ values (independent replications) } & \multirow{2}{*}{$\begin{array}{c}\text { Experimental } \\
\text { mean }^{c}\end{array}$} \\
\hline & & 1 & 2 & 3 & 4 & 5 & 6 & \\
\hline $\mathrm{NC}^{\mathrm{d}}$ & 0 & - & - & - & - & - & - & - \\
\hline $3 \mathrm{dpi}^{\mathrm{e}}$ & 0 & $32.61 \pm 2.12$ & $28.20 \pm 0.66$ & $30.21 \pm 0.30$ & $27.67 \pm 0.23$ & $26.51 \pm 0.11$ & $28.37 \pm 0.13$ & $28.93 \pm 2.17$ \\
\hline
\end{tabular}

a Number of samples that tested positive out of six independent inoculations or uninfected controls.

b Threshold cycle.

c Experimental mean and standard deviation based on six independent inoculations.

${ }^{\mathrm{d}}$ Negative control, DNA extracted from uninfected plants grown in a separate greenhouse.

e Days postinoculation.

tween their respective rDNA ITS regions (2). This allowed for the development of primers that could easily distinguish between these pathogens.

Although not a pathogen of Chrysanthemum $\times$ morifolium, the $\mathrm{Ph}-\mathrm{F} 2 / \mathrm{Ph}-\mathrm{R} 1$ primer set was also tested against genomic DNA from Puccinia graminis f. sp. tritici. The cereal rusts are common in the environment and are phylogenetically more similar to $P$. horiana than the other pathogens that infect Chrysanthemum $\times$ morifolium. No amplification was detected, even when using $100 \mathrm{ng}$ of template, an amount unlikely to be present in DNA extractions of chrysanthemum leaves. Some cross-reactions were reported by Alaei et al. (1), when the primers they developed were tested against $P$. drabae and $P$. trebouxi, but like $P$. graminis $\mathrm{f}$. sp. tritici, neither rust occurs in the same niche as $P$. horiana, minimizing the likelihood of cross-amplification with the nontarget organisms.

$P$. horiana remains a quarantine significant pest in the United States and in most countries where chrysanthemums are grown (3). Since most chrysanthemum varieties that are grown commercially are susceptible to the pathogen, the use of clean nursery stock and regular scouting for the disease remain the best preventative measures to combat white rust. The realtime PCR assay presented here demonstrates the specificity and sensitivity for the detection of $P$. horiana in infected tissue prior to the onset of symptoms under controlled conditions. However, further work will be required to determine the appropriate sampling methods to assist in these control measures.

\section{ACKNOWLEDGMENTS}

I gratefully acknowledge Amy Ruck for her technical assistance, and I thank Mary Palm, Anwar
Rizvi, and the many APHIS inspectors who helped in obtaining specimens and isolates of $P$. horiana and $P$. chrysanthemi. I also thank Jane Trolinger and Yoder Brothers, Inc. for arranging the shipment of chrysanthemum cuttings, Les Szabo for proving $P$. graminis genomic DNA, and Reid Frederick and Paul Tooley for critically reviewing the manuscript.

\section{LITERATURE CITED}

1. Alaei, H., Baeyen, S., Maes, M., Höfte, M., and Heungens, K. 2009. Molecular detection of Puccinia horiana in Chrysanthemum $\times$ morifolium through conventional and real-time PCR. J. Microb. Methods 76:136-145.

2. Alaei, H., De Backer, M., Nuytinck, J., Maes, M., Höfte, M., and Heungens, K. 2009. Phylogenetic relationships of Puccinia horiana and other rust pathogens of Chrysanthemum $\times$ morifolium based on rDNA ITS sequence analysis. Mycol. Res. 113:668-683.

3. Anonymous. 2004. Diagnostic protocols for regulated pests: Puccinia horiana. EPPO Bull. 34:209-211.

4. Arthur, J. C. 1962. Manual of the Rusts in the United States and Canada. G. B. Cummins, illustrator. Hafner Publishing, New York. (Reprinted from the 1934 edition with additional material by Cummins.)

5. Baker, J. J. 1967. Chrysanthemum white rust in England and Wales 1963-66. Plant Pathol. 16:162-166.

6. Barnes, C. W., and Szabo, L. J. 2007. Detection and identification of four common rust pathogens of cereals and grasses using realtime polymerase chain reaction. Phytopathology 97:717-727.

7. Cummins, G. B. 1978. Rust Fungi on Legumes and Composites in North America. University of Arizona Press, Tucson.

8. Firman, I. D., and Martin, P. H. 1968. White rust of chrysanthemums. Ann. Appl. Biol. 62:429-442.

9. Frederick, R. D., Snyder, C. L., Peterson, G. L., and Bonde, M. R. 2002. Polymerase chain reaction assays for the detection and discrimination of the soybean rust pathogens Phakopsora pachyrhizi and P. meibomiae. Phytopathology 92:217-227.

10. Ghignone, S., and Migheli, Q. 2005. The database of PCR primers for phytopathogenic fungi. Eur. J. Plant Pathol. 113:107-109.

11. Hennings, P. 1901. Einige neue japanische Uredineen. Hedwigia 40:25-26.

12. Hiratsuka, N. 1956. Three species of chrysan- themum-rusts in Japan and its neighboring districts. Sydowia, Ser. 2 Suppl. 1:34-44.

13. Horst, R. K., and Nelson, P. E. 1997. Compendium of Chrysanthemum Diseases. American Phytopathological Society, St. Paul, MN.

14. Kropp, B. R., Albee, S., Flint, K. M., Zambino, P., Szabo, L., and Thompson, S. V. 1995. Early detection of systematic rust infections of dyers woad (Isatis tinctoria) using the polymerase chain reaction. Weed Sci. 43:467-472.

15. Melching, J. S., Bromfield, K. R., and Kingsolver, C. H. 1983. The plant pathogen containment facility at Frederick, Maryland. Plant Dis. 67:717-722.

16. Newcombe, G. 2003. Puccinia tanaceti: Specialist or generalist? Mycol. Res. 107:797-802.

17. Punithalingam, E. 1968. Puccinia chrysanthemi. CMI Descriptions of Pathogenic Fungi and Bacteria. 175:1-2.

18. Rodgers, S. O., and Bendich, A. J. 1985. Extraction of DNA from milligram amounts of fresh, herbarium and mummified plant tissues. Plant Mol. Biol. Rep. 5:69-76.

19. Schaad, N. W., and Frederick, R. D. 2002 Real-time PCR and its application for rapid plant disease diagnostics. Can. J. Plant Pathol. 24:250-258.

20. Schaad, N. W., Frederick, R. D., Shaw, J., Schneider, W. L., Hickson, R., Petrillo, M. D., and Luster, D. G. 2003. Advances in molecular-based diagnostics in meeting crop biosecurity and phytosanitary issues. Annu. Rev. Phytopathol. 41:305-324.

21. White, T. J., Bruns, T., Lee, S., and Taylor, J. 1990. Amplification and direct sequencing of fungal ribosomal RNA genes for phylogenetics. Pages 315-322 in: PCR Protocols. M. A. Innis, D. H. Gelfand, J. J. Sninski, and T. J. White, eds. Academic Press, San Diego, CA.

22. Wilson, M., and Henderson, D. M. 1966. British Rust Fungi. Cambridge University Press, London.

23. Zandvoort, R. 1968. Wind dispersal of Puccinia horiana. Neth. J. Plant Pathol. 74:124127.

24. Zandvoort, R., Groenewegen, C. A. M., and Zadoks, J. C. 1968. On the incubation period of Puccinia horiana. Neth. J. Plant Pathol. 74:128-130.

25. Zhao, J., Wang, X. J., Chen, C. Q., Huang, L. L., and Kang, Z. S. 2007. A PCR-based assay for detection of Puccinia striiformis f. sp. tritici in wheat. Plant Dis. 91:1669-1674. 